\title{
Peran dan Tugas Guru dalam Melaksanakan 4 Fungsi Manajemen EMASLIM dalam Pembelajaran di Workshop
}

\author{
Yogia Prihartini ${ }^{1}$, Wahyudi ${ }^{2}$, Nur Hasnah ${ }^{3}$, Muhmamad Ridha DS $^{4}$ \\ 1,2 Dosen di UIN Sulthan Thaha Saifuddin Jambi \\ ${ }^{3}$ Dosen di IAIN Bukit Tinggi \\ ${ }^{4}$ Dosen di IAIN Kerinci \\ Email:yogia_prihartini@uinjambi.ac.id
}

\begin{abstract}
ABSTRAK. Dalam dunia pendidikan, keberadaan peran dan fungsi guru merupakan salah satu faktor yang sangat signifikan. Guru merupakan bagian terpenting dalam proses belajar mengajar, baik di jalur pendidikan formal maupun informal. Oleh sebab itu, dalam setiap upaya peningkatan kualitas pendidikan di tanah air, tidak dapat dilepaskan dari berbagai hal yang berkaitan dengan ek sistensi guru itu sendiri. Pembelajaran pada hakikatnya adalah proses sebab-akibat. Guru sebagai pengajar merupakan penyebab utama terjadinya proses pembelajaran siswa, meskipun tidak semua belajar siswa merupakan akibat guru yang mengajar. Oleh sebab itu, guru sebagai figur sentral harus mampu menetapkan strategi pembelajaran yang tepat sehingga dapat mendorong terjadinya perbuatan belajar siswa yang aktif, produktif, dan efesien. Guru hendaknya dalam mengajar harus memperhatikan kesiapan, tingkat kematangan, dan cara belajar siswa.Maka Guru menempati posisi kunci dan strategis dalam menciptakan suasana belajar yang kondusif dan menyenangkan untuk mengarahkan siswa agar dapat mencapai tujuan secara optimal. Untuk guru harus mampu menempatkan dirinya sebagai diseminator, informator, transmitter, transformator, organizer, fasilitator, motivator, dan evaluator bagi terciptanya proses pembelajaran siswa yang dinamis dan inovatif.
\end{abstract}

Kata kunci: manajemen, emaslim, pembelajaran, workshop

\section{PENDAHULUAN}

Guru merupakan salah satu figur atau sosok yang dijadikan panutan dan tauladan dalam setiap aktivitasnya, dalam istilah jawa guru adalah sosok yang digugu dan ditiru. Karena itu ada pepatah yang menyatakan bahwa guru kencing berdiri, murid kencing berlari. Rasanya istilah dan pepatah ini tidak berlebihan memang, karena bagaimanapun figur guru merupakan sosok yang akan memberikan tauladan kepada peserta didik khususnya, dan bagi masyarakat umumnya.

Membicarakan tentang guru, memang tidak akan pernah habis-habisnya, terlebih lagi sekarang ini, profesi guru sudah mendapat kedudukan yang cukup baik di negara Indonesia tercinta, sudah mendapat pengakuan yakni dengan keluarnya Undang-Undang Nomor 14 Tahun 2005 tentang Guru dan Dosen. Keluarnya Undang-undang ini berimplikasi pada profesi guru tersebut, diantaranya adalah profesi guru sudah merupakan salah satu profesi incaran bagi sebagian generasi muda, yang konon khabarnya dahulu, mahasiswa yang masuk di fakultas keguruan atau institut keguruan berasal dari strata menengah ke bawah, dari 
kampung, atau karena tidak lulus masuk fakultas kedokteran, dan lain sebagainya. Tetapi sekarang sudah sebaliknya.

Munculnya fenomena di atas, yang tentu saja sangat membanggakan kaum pendidik, ditengah berbagai persoalan kompleks pendidikan yang dihadapi oleh bangsa ini. Lalu, sehubungan dengan hal tersebut di atas, maka timbul sederetan pertanyaan, diantaranya bagaimanakah peran dan tugas Guru sebeanrnya dikaitkan dengan empat fungsi manajemen EMASLIM? Apakah peran guru tersebut sudah sejalan dengan tuntutan? Apakah dengan peran dan tugas guru tersebut sudah berjalan dengan optimal atau sebaliknya? Serta banyak pertanyaan lain terkait dengan peran dan tugas guru tersebut.sehubungan dengan hal tersebut, maka untuk menjawab pertanyaan tersebut, maka dalam makalah ini penulis mencoba mengupas dan membahas dan mengkaji tentang fenomena terkait dengan peran dan tugas guru dalam melaksanakan 4 fungsi manajemen EMASLIM.

\section{PEMBAHASAN}

\section{Peran Guru dalam Melaksanakan 4 Fungsi Manajemen EMASLIM Guru sebagai Educator}

Peran guru sebagai educator (pendidik) merupakan peran yang begitu sentral dalam pendidikan. Menurut Mulyasa (2005: 37) "Guru adalah pendidik, yang menjadi tokoh, panutan, dan identifikasi bagi para peserta didik, dan lingkungannya". Karena itu idealnya seorang guru mesti memiliki kualitas pribadi, meliputi rasa tanggung jawab, disiplin, penuh cinta kasih, bermoral, berwibawa, serta mampu memahami keadaan peserta didik secara komprehensif.

Peran guru selaku pendidik berbeda dengan pengajar. Pengajar lebih kepada orientasinya transfer of knowledge. Tetapi sebagai pendidik lebih dari pengajar, ini berkenaan dengan bagaimana guru memberikan bimbingan, membina, memberikan motivasi, jadi tidak hanya sekedar pentranfer ilmu pengetahuan saja. Salah satu contoh adalah, ketika anak ada yang mengalami permasalahan dalam belajar, sebagai pendidik, guru harus mampu mencari tahu apa penyebab permasalahan anak tersebut, sehingga bias dicarikan permasalahannya. Contoh lain adalah ketika seorang anak tidak termotivasi dalam mengikuti pembelajaran, guru yang berperan sebagai pendidik, akan berupaya untuk senantiasa memberian support atau dorongan, agar ia termotivasi dalam mengikuti pembelajaran. Karena itu, maka guru yang berperan sebagai pendidik, memang lebih besar pengaruhnya dalam membentuk kepribadian dan mental anak, tidak hanya sekedar orang yang berfungsi menyampaikan materi pembelajaran saja.Tugas pertama guru adalah mendidik anak didik sesuai dengan materi pelajaran yang diberikan kepadanya. Sebagai educator, ilmu adalh sangat utama. Membaca, menulis, berdiskusi, mengikuti inormasi dan responsive terhadap masalah kekinian sangat menunjang peningkatan kualitas ilmu guru.

Pendidik adalah tenaga kependidikan yang berkualifikasi sebagai guru, dosen, konselor, pamong belajar, widyaiswara, tutor, instruktur, fasilitator, dan sebutan lainnya serta berpartisipasi dalam penyelenggaan pendidikan (UU No.20/2003, Pasal1, ayat 5) Dalam (Pokja :2005). Jadi pendidik adalah orang yang memberikan dan menyampaikan ajaran-ajaran berupa ilmu pengetahuan kepada seseorang atau beberapa orang. Pendidik juga pelaksana dan penanggung jawab kegiatan pendidikan dalam situasi pendidikan. 
Pendidik bertugas sebagai penyelenggara proses pembelajaran agar pada diri peserta didik berkembang suasana belajar. Proses pembelajaran antara pendidik dan peserta didik mempunyai dua kandungan pokok yaitu kewibawaan dan kewiyatan. Kewibawaan merupakan unsur-unsur yang menentukan kualitas hubungan antara peserta didik dan pendidik; sedang kewiyatan merupakan unsur-unsur yang menentukan isi hubungan antara pendidik dan peserta didik itu. Keduanya tersingkrosasikan dalam di dalam apa yang disebut proses pembeljaran. Pendidik harus mampu memfasilitasi dan menjadi fasilitator bagi pengembangan peserta didik yang diwarnai secara kental oleh suasana kehangatan dan penerimaan, keterbukaan, dan ketulusan, penghargaan, kepercayaan, pemahaman empatik, kecintaan dan penuh perhatian.

\section{Guru sebagai Manager}

Sebagai manager (pengelola) kelas, guru berperan dalam menciptakan suasana atau iklim belajar yang kondusif, yang dapat menyebabkan sisawa dapat belajar secara nyaman. Pengelolaam di sisni bisa dalam bentuk pengelolalaan lingkungan fisik dan lingkungan non fisik. Sebagai seorang manager, guru perlu mengelola kedua lingkungan ini menjadi kondusif dalam pembelajaran. Lingkungan ini diatur dan diawasi agar kegiatan-kegiatan belajar agar terarah kepada pencapaian tujuan pembelajaran yang diinginkan. Lingkungan yang baik ialah yang bersifat menantang dan merangsang siswa unuk belajar, memberikan rasa aman dan kepuasan dalam mencapai tujuan. Tujuan umum pengelolaan kelas ialah menyediakan menggunakan fasilitas kelas untuk bermacam-macam kegiatan belajar dan mengajar agar mencapai hasil yang baik. Sedangkan tujuan khususnya adalah mengembangkan kemampuan siswa dalam menggunakan alat-alat belajar, menyediakan kondisi-kondisi yang memungkinkan siswa belajar dan belajar, serta membantu siswa untuk memperoleh hasil yang diharapkan.

Guru juga sebagai pemimpin kelas, karena itu ia harus bisa menguasai, mengendalikan. Dan mengarahkan kelas menuju tercapainya tujuan pembelajaran yang berkualitas. Sebagai seorang pemimpin, guru harud terbuka, demokratis, egaliter, dan mengjhindari cara-cara kekerasan. Dan guru juga harus pandai membaca potensi anak didiknya uan beragam, dan mampu menggunakan multi pendekatan dalam mengajar demi menyesuaikan potensi dan spesifikasi yang beragam dari anak didiknya, serta memberikan saksi kepda anak didiknya yang melanggar aturan dengan tegas, adil, dan bijaksana.

Dalam melaksanakan pengelolaan pembelajaran menurut Sanjaya (2011: 24) “Ada dua macam kegiatan yang harus dilakukan, yaitu mengelola sumber belajar dan melaksanakan peran sebagai sumber belajar itu sendiri". Ini berarti bahwa guru sebagai pengelola tidak hanya berperan sebagai pengelola sumber belajar tetapi juga berperan sebagai pelaksana sumber belajar itu sendiri. Karena itu peran ini mesti dipahami oleh seorang guru dengan sebaik mungkin. Selanjutnya Sanjaya (2011) juga mengemukakan sebagai manajer, guru memiliki empat fungsi umum, yaitu: merencanakan, mengorganisasikan, memimpin dan mengawasi.

1) Merencanakan

Sebagai seorang manager, guru berfungsi sebagai perencana. Fungsi ini merupakan fungsi yang sangat penting bagi seorang manager. Dimana perencanaan yang baik, akan berpengaruh terhadap pelaksanaan pembelajaran. Hal ini sesuai dengan pendapat Uno (2009) bahwa perencanaan pembelajaran diperlukan agar dapat dicapai perbaikan pembelajaran. 
Kegiatan ini meliputi pembuatan Silabus, Rencana Pelaksanaan Pembelajaran, yang didalamnya meliputi penentuan tujuan yang ingin dicapai, alokasi waktu yang disediakan, penggunaan startegi dan metode pembelajaran, penentuan media pembelajaran sampai kepada bagaimana mengevaluasi pembelajaran. jika hal ini dilaksanakan oleh guru, maka arah pembelajaran akan lebih terarah, dan hasil yang diharapkan akan lebih optimal, dibandingkan dengan guru yang tidak membuat perancaaan dengan baik. Oleh karena itu, peran guru sebagai perencana pembelajaran adalah sangat penting.

\section{2) Mengorganisasikan}

Fungsi yang kedua guru sebagai manager adalah mengorganisasikan. Yang namanya pembelajaran merupakan suatu sistem, diamana di dalamnya terdiri dari berbagai komponen yang saling terkait dan saling berhubungan. Artinya adalah ketika pembelajaran ingin dilaksanakan dengan baik, maka komponen-komponen yang ada dalam pembelajaran tersebut mestilah diorganisasikan dengan baik, sehingga pembelajaran bisa berlangsung dengan kondusif. Misalnya bagaimana mengatur sumber belajar, bagaimana mengaturalat pembelajaran, kapan digunakan dan sipa melaksanakan. Karena itu dibutuhkan organisasi, agar tidak terjadi kesimpangsiuran dalam pembelajaran.

\section{3) Memimpin}

Fungsi yang ketiga yang tidak kalah pentingnya adalah memimpin. Sebagai seorang guru, akan berhadapan dengan siswa yang memiliki karakteristik yang beragam. Karena itu dituntut kemampuan guru untuk mengelola siswa yang beragam karakteristiknya tersebut. Diantaranya bagaiaman mendorong siswa agar mau belajar, membimbing siswa yang mengalamai kesulitan dalam belajarserta membangkitkan motivasi belajar siswa agar mereka bergairah mengikuti proses pembelajaran, sehingga dengan demikian nantinya diharapkan hasil pembelajaran akan dapat dicapai dengan baik oleh siswa.

4) Mengawasi

Fungsi berikutnya adalah mengawasi, artinya adalah melihat segala sesuatu, apakah sudah berfungsi sebagaimana mestinya atau belum dalam rangka pencapaian tujuan. Soerang guru dituntut untuk memantau proses pembelajaran dengan sebaik mungkin, apakah sudah terlaksana dengan baik, apakah ada siswa yang membutuhkan bantuan dalam proses pembelajaran. ketika fungsi ini dijalankan oleh seorang guru dengan baik, maka tidak akan pernah ada siswa yang tidak tuntas dalam pembelajaran. karena dari awal guru sudah tahu, mana anak yang bisa dan mana anak yang mengalami kendala dalam pembelajaran. ketika ada ada anak yang mengalami kendala dalam belajar (tidak tuntas) maka guru akan melasanakan remedial teaching, agar anak tersebutr bisa tuntas. Tetapi sebaliknya jika fungsi pengawasan tidak jalan, maka guru tidak akan dapat mengetahui mana anak yang memerlukan bantuan.

\section{Guru sebagai Actor}

Sebagai actor, guru adalah sebagai pemain dalam pembelajaran, artinya guru adalah seorang yang melakukan apa yang sudah direncanakan dalam rencana pembelajaran yang telah disusun sebelumnya. Ini didukung oleh pendapat Mulyasa (2005: 58) bahwa "Sebagai seorang aktor, guru harus melakukan apa yang ada dalam naskah yang telah disusun dengan mempertimbangkan pesan yang akan disampaikan kepada penonton”. Pesan dalam hal ini 
adalah materi atau informasi yang ingin diterima oleh anak. Karena itu guru sebagai seorang aktor, harus mampu memainkan perannya dengan baik, apakah dengan melibatkan media, sehingga pesan yang ingin disampaikan dapat diterima oleh anak dengan maksud yang sama seperti yang ingin disampaikan oleh guru. Seorang guru selain mempersiapkan diri dengan baik, dengan cara memahami rencana pembelajaran, juga mesti didukung oleh pengetahuan yang mendalam serta sikap mental yang baik, agar kiranya tujuan yang menjadi sasaran akhir dari pembelajaran dapat tercapai dengan baik.

Selain itu sebagai seorang aktor, guru dituntut harus menguasai materi pembelajaran yang menjadi tanggung jawabnya, memperbaiki keterampilan dalam pembelajaran, menguasai urutan penyajian materi pembelajaran, serta yang tidak kalah pentingnya adalah berusaha senantiasa meningkatkan minat belajar siswa, dengan mengembangkan aspek-aspek strategi pembelajaran yang tepat. Karena bagaimanapun seorang aktor, tuntutannya tentu adalah bagaimana penonton dalam hal ini siswa mampu bertahan selama proses pembelajaran, dan selain bertahan, siswa mampu menyerap materi pembelajaran yang disampaikan. Inilah peran guru sebagai aktor, intinya adalaha bagaimana seoran guru bisa memainkan perannya dalam pembelajaran dengan optimal, sehingga siswa bisa tertarik dan termotivasi dalam mengikuti pembelajaran. Ibarat sebuah film atau sinetron guru yang baik adalah guru yang mampu menyajkan pembelajaran dan penyajian itu bias diserap dengan baik oleh anak.

\section{Guru sebagai Supervisor}

Dalam proses pembelajaran siswa selaku peserta didik tentu saja membutuhkan bantuan dari orang lain untuk membantu memecahkan masalah yang dihadapi dalam pembelajaran. Misalnya bagaimana anak mampu berkembang dengan baik. Orang yang berfungsi membantu anak dalam hal ini adalah guru atau supervisor. Menurut P. Adam dan Frank G Dickey dalam Soetopo dan Soemanto (1984: 39) "Supervisi adalah program yang berencana untuk memperbaiki pembelajaran". ini artinya adalah bahwa seorang guru harsulah mampu mendorong pembelajaran dengan sebaik mungkin. Program ini akan mampu berjalan dengan baik, jika supervisor memiliki keterampilan dan cara kerja yang efisien. Agar supervisi bisa berlangsung dengan baik, maka seorang supervisor harus memahami prinsip-prinsip supervisi, diantaranya adalah sebagai berikut: 1) supervisi harus dilaksanakan secara demokratis dan kooperatif. 2) supervisi harus kreatif dan konsrtuktif. 3) supervisi harus scientific dan efektif. 4) supervisi harus berdasarkan kenyataan.

\section{Guru sebagai Leader}

Guru juga seorang pemimpin kelas. Karena itu, ia harus bisa menguasai, mengendalikan, dan mengarahkan kelas menuju tercapainya tujuan pembelajaran yang berkualitas. Sebagai seorang pemimpin, guru harus terbuka, demokratis, egaliter, dan menghindari cara-cara kekerasan. Karena belajar di ruang kelas, merupakan kegiatan yang terencana dan tidak insidental. Oleh karena itu seorang guru harus mampu membangun suasana pembelajaran yang mampu mendukung suasana pembelajaran ke arah yang lebih baik. Misalnya guru harus mampu mengarahkan proses pembelajaran secara bertahap, menghentikan kegiatan pembelajaran pada unit tertentu dan maju ke unit berikutnya. Selian itu sebagai pemimpin, guru harus mampu mengarahkan pembelajaran dengan sebaik mungkin menuju tujuan yang diharapkan. Pemimpin yang baik juga mampu mengelola sumberdaya yang ada dalam kelas itu dengan sebaik-baiknya, sehingga tujuan tercapai. 
Sumberdaya yang ada dalam kelas itu adalah siswa selalku peserta ddik, fasilitas, metode, media dan lain sebagainya. Jika itu mampu dilakukan oleh seorang guru, maka diharapkan akan mampu mencapai tujuan pembelajaran dengan efektif dan efisien.

\section{Guru sebagai Instruktur}

Peran berikutnya adalah guru sebagai instruktur. Menurut Tim Penyusun Kamus Pusat Pembinaan dan Pengembangan Bahasa (1990: 334) "Instruktur adalah orang yang bertugas mengajarkan sesuatu dan sekaligus memberikan latihan dan bimbingannya; pengajar". Dengan demikian instruktur adalah pengajar. Jadi dalam hal uini peran guru sebagai instruktur sama dengan guru sebagai pengajar. Peran guru sebagai pengajar menurut Mulyasa (2005: 38) "Guru membantu peserta didik yang sedang berkembang untuk mempelajari sesuatu yang belum diketahuinya, membentuk kompetensi, dan memahami materi standar yang dipelajari”. Seiring dengan berkembangnya teknologi, khususnya teknologi informasi yang begitu pesat perkembangannya, dimana anak dapat belajar dari berbagai sumber belajar, belum mampu menggantikan peran dan fungsi guru, hanya sedikit menggeser atau mengubah fungsinya, itupun terjadi di kota-kota besar saja, ketika para peserta didik memiliki berbagai sumber belajar di rumahnya.

\section{Guru sebagai Integrator}

Peran berikutnya guru adalah sebagai integrator. Integrator artinya adalah orang yang mampu memadukan semua pihak. Karena guru bekerja dalam sebuah sistem, banyak sekali komponen yang terlibat di dalamnya. Diantaranya bagaimana bisa memadukan fasilitas, sumberdaya manusia yang ada dengan sebaik-baiknya, dengan tujuan agar hasil pembelajaran dapat tercapai secara optimal. Selain dari sebagai integrator, guru juga harus mampu menggabung-gabungkan sesuatu yang terpisah-pisah menjadi satu kesatuan yang mendukung pencapai tujuan pembelajaran. Misalnya metode, kalau ia berdiri sendiri maka, metode sebagai cara belum aan berjalan optimal, untuk itu perlu didukung dengan media, kemampuan guru menggunakan media. Intinya adalah komponen yang terkait dalam pembelajaran yang pada awalnya masih berdiri sendiri, hasrus mampu diintegrasikan oleh seorang guru menjadi satu-kesatuan yang memiliki arti.

\section{Guru sebagai Motivator}

Sebagai motivator guru hendaknya mampu memberikan motivasi, semangat, dan dorongan kepada siswa untuk mampu belajar dengan baik. Motivasi berpangkal dari kata motif yang dapat diartikan sebagai daya penggerak yang ada di dalam diri seseorang untuk melakukan aktivitas-aktivitas tertentu demi tercapainya suatu tujuan. Bahkan motif dapat diartikan sebagai suatu kondisi intern (kesiapsiagaan). Adapun menurut Mc. Donald, motivasi adalah perubahan energi dalam diri seseorang yang ditandai dengan munculnya "feeling" dan di dahului dengan tanggapan terhadap adanya tujuan. Dari pengertian yang dikemukakan oleh Mc. Donald ini mengandung tiga elemen/ciri pokok dalam motivasi itu, yakni motivasi itu mengawalinya terjadinya perubahan energi, ditandai dengan adanya feeling, dan dirangsang karena adanya tujuan.

Jadi, intinya bahwa motivasi merupakan kondisi psikologis yang mendorong seseorang untuk melakukan sesuatu. Dalam kegiatan belajar, motivasi dapat dikatakan sebagai keseluruhan daya penggerak di dalam diri siswa yang menimbulkan, menjamin kelangsungan dan 
memberikan arah kegiatan belajar, sehingga diharapkan tujuan dapat tercapai. Dalam kegiatan belajar, motivasi sangat diperlukan, sebab seseorang yang tidak mempunyai motivasi dalam belajar, tidak akan mungkin melakukan aktivitas belajar. Motivasi ada dua, yaitu motivasi Intrinsik dan motivasi ektrinsik.

1) Motivasi Intrinsik. Jenis motivasi ini timbul dari dalam diri individu sendiri tanpa ada paksaan dorongan orang lain, tetapi atas dasar kemauan sendiri.

2) Motivasi Ekstrinsik. Jenis motivasi ini timbul sebagai akibat pengaruh dari luar individu, apakah karena adanya ajakan, suruhan, atau paksaan dari orang lain sehingga dengan keadaan demikian siswa mau melakukan sesuatu atau belajar.

Bagi siswa yang selalu memperhatikan materi pelajaran yang diberikan, bukanlah masalah bagi guru. Karena di dalam diri siswa tersebut ada motivasi, yaitu motivasi intrinsik. Siswa yang demikian biasanya dengan kesadaran sendiri memperhatikan penjelasan guru. Rasa ingin tahunya lebih banyak terhadap materi pelajaran yang diberikan. Berbagai gangguan yang ada disekitarnya, kurang dapat mempengaruhinya agar memecahkan perhatiannya.Lain halnya bagi siswa yang tidak ada motivasi di dalam dirinya, maka motivasi ekstrinsik yang merupakan dorongan dari luar dirinya mutlak diperlukan. Di sini tugas guru adalah membangkitkan motivasi peserta didik sehingga ia mau melakukan belajar.

Ada beberapa strategi yang bisa digunakan oleh guru sebagai motivator untuk menumbuhkan motivasi belajar siswa, yakni:

1) Menjelaskan tujuan belajar ke peserta didik.Pada permulaan belajar mengajar seharusnya terlebih dahulu seorang guru menjelaskan mengenai Tujuan Instruksional Khusus yang akan dicapainya kepada siwa. Makin jelas tujuan maka makin besar pula motivasi dalam belajar.

2) Hadiah

Berikan hadiah untuk siswa yang berprestasi. Hal ini akan memacu semangat mereka untuk bisa belajar lebih giat lagi. Di samping itu, siswa yang belum berprestasi akan termotivasi untuk bisa mengejar siswa yang berprestasi.

3) Ciptakan saingan/kompetisi

Agar siswa termotivasi dalam mengikuti pembelajaran, maka guru idealnya perlu melaksanakan kompetisi atau persaingan, tetapi kompetisi di sini adalah kompetisi yang positif, bukan sebaliknya kompetisi yang negative, yang akan merusak iklim pembelajaran yang kondusif. Guru berusaha mengadakan persaingan di antara siswanya untuk meningkatkan prestasi belajarnya, berusaha memperbaiki hasil prestasi yang telah dicapai sebelumnya.

4) Berilah pujian

Sudah sepantasnya siswa yang berprestasi untuk diberikan penghargaan atau pujian. Tentunya pujian yang bersifat membangun. Seorang siswa selaku manusia, sepantasnyalah diberikan pujian atau penghargaan jika ampu melakukan sesuatu yang baik dan positif. Adakalanya seorang guru selama ini, cenderung cepat memberikan cacian ketika ada siswa yang mengalami kesalahan, dan cenderung diam ketika siswa melakukan sesuatu yang positif atau berhasil. Sehubungan dengan hal itu, maka guru sekarang ini dituntut untuk memberikan pujian, karena selaku manusia cenderung ingin dihargai dan dipuji. Ketika itu dilakukan maka motivasi siswa akan meningkat.

5) Berilah komentar terhadap hasil pekerjaan siswa 
Siswa butuh penghargaan. Penghargaan bisa dilakukan dengan memberikan komentar yang positif terhadap hasil pekerjaan siswa. Karena itu setiap pekerjaan siswa hendaknya dilakukan penilaian dan diberikan komentar.

6) Membangkitkan dorongan kepada anak didik untuk belajar.

Strateginya adalah dengan memberikan perhatian maksimal ke peserta didik. Hal yang tidak kalah pentingnya dalam memberikan motivasi epada siswa, adalah dengan memberikan perhatian, misalnya dengan menyapa siswa pada pagi hari, menanyakan kondisi anak, dan banyak contoh lainnya yang dapat meningkatkan perhatian siswa.

\section{KESIMPULAN}

Berdasarkan uraian di atas, maka dapat dipahami bahwa banyak sekali peran guru dalam pembelajaran mulai dari guru sebagai educator, manager, actor, supervisor, leader, instruktur, integrator, dan motivator. Kesemua peran guru tersebut seyogyanya dapat dijalankan dengan sebaik mungkin khususnya dalam pelaksanaan di kelas atau workshop, agar peran guru tersebut yang begitu banyak dapat berkontribusi positif terhatap kualitas pembelajaran dan lebih khususnya terhadap hasil belajar siswa. Sehubungan dengan hal tersebut, maka jika menginginkan hasil belajar yang baik dan meningkat, maka masing-masing guru perlu memahami peran dan fungsi tersebut. Karena bagaimanapun guru merupakan salah satu sosok penentu dalam peningkatan kualitas pembelajaran dengan tidak mengecilkan arti komponen lain dalam pembelajaran. Guru memiliki tugas yang beragam yang berimplementasi dalam bentuk pengabdian. Tugas tersebut meliputi bidang profesi, bidang kemanusiaan dan bidang kemasyarakatan. Tugas guru sebagai profesi meliputi mendidik, mengajar dan melatih. Mendidik berarti meneruskan dan mengembangkan nilai-nilai hidup dan kehidupan. Mengajar berarti meneruskan dan mengembangkan ilmu pengetahuan dan teknologi. Sedangkan melatih berarti mengembangkan keterampilan-keterampilan pada siswa. Guru adalah posisi yang strategis bagi pemberdayaan dan pembelajaran suatu bangsa yang tidak mungkin digantikan oleh unsur manapun dalam kehidupan sebuah bangsa sejak dahulu. Semakin signifikannya keberadaan guru melaksanakan peran dan tugasnya semakin terjamin terciptanya kehandalan dan terbinanya kesiapan seseorang. Dengan kata lain potret manusia yang akan datang tercermin dari potret guru di masa sekarang dan gerak maju dinamika kehidupan sangat bergantung dari "citra" guru di tengah-tengah masyarakat.

\section{KESIMPULAN}

Ahmad Sjalabi. Sejarah Pendidikan Islam. Jakarta: Bulan Bintang. 1973

Ali Imron. Belajar dan Pembelajaran. Jakarta: Pustaka Jaya. 1996

Adams, H.F. dan F.G. Dickey. Basic Principles of Supervision. New York: Amerikan Book Company. 1959.

Alexander Mackie College of Advance Education. Supervision of Practice Teaching. Primary Program, Sydney, Australia. 1981 
Ditjen Dikti Depdikbud, Wawasan Kependidikan Guru, Proyek Pengembangan Institusi Pendidikan Tinggi, Ditjen Dikti Depdikbud Jakarta. 1982

E. Mulyasa. Menjadi Guru Profesional. Bandung: Remaja Rosdakarya. 2005.

Gastill, Jhon.” A Definition of Democratic Leadership", Leadership, ed. Keith Grint. Oxford: Oxford University Press. 2000.

Ibrahim Bafadal. Supervisi Pengajaran Teori dan Aplikasi dalam Membina Profesional guru. Jakarta: Bumi Aksara.1992

J. Winardi. Motivasi dan Pemotivasian dalam Manajemen. Jakarta: PT Raja Grafindo. 2001

Jalaluddin dan Abdullah Idi. Filasafat Pendidikan. Jakarta: Gaya Media. 1997

Hendyat Soetopo dan Wasty Soemanto, Kepemimpinan dan Supervisi Pendidikan, Jakarta:

PT Bina Aksara. 1984

Hasibuan, J.J., Ibrahim, dan A.J.E. Toen Lioe, Proses Belajar Mengajar, Bandung: PT Remaja Rosdakarya. 1991

Malayu S. P. Hasibuan. Manajemen Sumber Daya Manusia. Jakarta: Bumi Aksara. 2001

Mulyasa, E. Menjadi Guru Profesional: Menciptakan Pembelajaran Kreatif dan Menyenangkan. Bandung: Remaja Rosdakarya. 2005.

Ngalim Purwanto. Psikologi Pendidikan. Bandung: Remaja Rosdakarya. 1996

Oemar Hamalik. Psikologi Manajemen Penuntun Bagi Pemimpin. Bandung: Trigenda Karya. 1993

Pandji Anoraga dan Sri Suyati. Perilaku Keorganisasia. Jakarta: PT Dunia Pustaka Jaya. 1995

S. Nasution. Berbagai Pendekatan dalam Proses Belajar dan Mengajar. Jakarta: Bumi Aksara. 2005

Sardiman A.M. Interaksi \& Motivasi Belajar Mengajar. Jakarta: Rajawali Pers. 2010

Sukanto Reksohadiprodjo. Pengantar Manajemen. Jakarta: Universitas Terbuka. 1996

Syaiful Bahri Djamarah. Psikologi Belajar. Jakarta: Rineka Cipta. 1999.

Sahertian, P.A. dan Frans Mataheru, Prinsip dan Teknik Supervisi Pendidikan, Surabaya: Usaha Nasional. 1981

Sanjaya, Wina. Strategi Pembelajaran Berorientasi Standar Proses Pendidikan. Jakarta: Kencana Prenada Media. 2011.

Soetopo, Hendiyat dan Wasty Soemanto. Kepemimpinan dan Supervisi Pendidikan. Tanpa Kota: Bina Aksara. 1984.

Thursan Hakim. Belajar Secara Efektif. Jakarta: Puspa Swara.2001

Undang-undang Republik Indonesia Nomor 20 tahun 2003 Tentang Sistem Pendidikan Nasional.

Undang-undang Republik Indonesia Nomor 14 Tahun 2005 Tentang Guru dan Dosen. 2006. Jakarta: PB PGRI. 
Uno, Hamzah B. Perencanaan Pembelajaran. Jakarta: Bumi Aksara. 2009.

Winardi. Kepemimpinan dalam Manajemen. Jakarta: Rineka Cipta. 2000

Wiles, J. dan J. Bondi. Supervision: A Guide to Practice. Second Edition. Columbus: Charles E. Merrill Publishing Company. 1986. 